\title{
Pola Kepekaan Bakteri Penyebab Pneumonia terhadap Antibiotika di Laboratorium Mikrobiologi RSUP Dr. M. Djamil Padang Periode Januari sampai Desember 2011
}

\author{
Jaka Kurniawan ${ }^{1}$, Erly ${ }^{2}$, Rima Semiarty ${ }^{3}$
}

\begin{abstract}
Abstrak
Peningkatan resistensi bakteri penyebab pneumonia terhadap beberapa antibiotika yang lazim digunakan oleh klinisi dalam pemberian terapi empirik akan menyebabkan berkurangnya keefektifan terhadap terapi pneumonia. Hal ini akan berdampak semakin tingginya morbiditas dan mortalitas yang disebabkan oleh infeksi pneumonia. Tujuan penelitian ini adalah untuk mengetahui pola kepekaan bakteri penyebab pneumonia terhadap antibiotika di Laboratorium Mikrobiologi RSUP. Dr. M. Djamil Padang periode Januari 2011 - Desember 2011. Metode penelitian yang digunakan adalah deskriptif retrospektif terhadap data sekunder hasil uji kepekaan antibiotika dan jenis kuman dari 432 pasien, menunjukkan jenis bakteri penyebab pneumonia adalah Klebsiella sp, Streptococcus $\alpha$ haemolyticus, Staphylococcus aureus, Pseudomonas aeuruginosa, proteus sp, Basillus, Escherichia coli dan Enterobacter. Pola kepekaannya menunjukkan bahwa rata-rata semua bakteri tersebut mempunyai sensitivitas tertinggi terhadap Netilmicin, Meropenem, dan Sulbactam + Cefoperazone. Resistensi tertinggi ditunjukkan oleh Erithromycin, Ampicillin, Sulfamethroxazole + Trimethroprime, Tetracyclin, dan Choramphenicol.
\end{abstract}

Kata kunci: antibiotika, bakteri penyebab pneumonia, pola kepekaan

\begin{abstract}
Increased resistance of bacteria that cause pneumonia to some antibiotics that are commonly used by clinicians in the provision of empiric therapy, it will cause a reduction in the effectiveness of the treatment of pneumonia. This will lead to increasing morbidity and mortality caused by pneumonia infection. The objective of this study wass to determine the sensitivity pattern of bacteria that cause pneumonia to antibiotics in the Department of Microbiology Laboratory. Dr. M. Djamil Hospital Padang period from January 2011 to December 2011. The research method used was a descriptive and retrospective review of secondary data and antibiotic sensitivity test results of 432 patients types of germs. The results indicated the type of bacteria that cause pneumonia are Klebsiella sp, Streptococcus a haemolyticus, Staphylococcus aureus, Pseudomonas aeuruginosa, Proteus sp, Basillus, Escherichia coli, and Enterobacter. Sensitivity pattern showed that the average of all the bacteria has the highest sensitivity to Netilmicin, Meropenem, and Sulbactam + Cefoperazone, Highest resistance shown by Erithromycin, Ampicillin, Sulfamethroxazole Trimethroprime + , Tetracycline, and Choramphenicol.
\end{abstract}

Keywords: antibiotics, the bacteria that caused pneumonia, sensitivity pattern

Affiliasi penulis: 1. Pendidikan Dokter FK UNAND (Fakultas Kedokteran Universitas Andalas Padang), 2. Bagian Mikrobiologi FK UNAND, 3. Bagian IImu Kesehatan Masyarakat FK UNAND Korespondensi: Jaka Kurniawan, E-mail : rainprince21@yahoo.com, Telp: 085766000887

\section{PENDAHULUAN}

Penyakit infeksi merupakan salah satu masalah kesehatan di dunia, termasuk di Indonesia. Survei Kesehatan Rumah Tangga tahun 2010 menunjukkan 
bahwa penyakit infeksi merupakan penyebab kedua kematian setelah penyakit kardiovaskuler. Laporan World Health Organisation pada tahun 2004 menyebutkan penyebab kematian tertinggi akibat penyakit infeksi di dunia adalah Infeksi Saluran Pernapasan Akut (ISPA). ${ }^{1-3}$

Infeksi saluran pernapasan akut merupakan Infeksi pada saluran pernapasan atas maupun bawah yang disebabkan oleh masuknya organisme (bakteri atau virus) ke dalam saluran pernapasan yang berlangsung selama 14 hari. ISPA dapat disebabkan oleh berbagai macam organisme, namun yang terbanyak adalah infeksi yang disebabkan oleh virus dan bakteri. Virus merupakan penyebab terbanyak infeksi saluran nafas atas akut seperti rhinitis, sinusitis, faringitis, tonsilitis, dan laringitis. Hampir 90\% dari infeksi tersebut disebabkan oleh virus dan hanya sebagian disebabkan oleh bakteri. Pada infeksi saluran nafas bawah akut seperti bronkitis, bronkiolitis dan pneumonia penyebab terbanyaknya adalah infeksi bakteri, yang sebagian besar berasal dari penyebaran infeksi saluran pernapasan atas.,

Pneumonia merupakan bentuk utama Infeksi Saluran Napas Bawah Akut (ISNBA) di parenkim paru yang dapat menimbulkan morbiditas dan mortalitas yang tinggi serta kerugian produktifitas kerja. Hasil Survei Kesehatan Rumah Tangga Depkes RI tahun 2010 menyebutkan bahwa penyakit infeksi saluran pernapasan napas bawah menempati urutan kedua sebagai penyebab kematian di Indonesia. Berdasarkan survei mortalitas yang disebabkan oleh ISPA pada tahun 2005 di 10 provinsi, didapatkan bahwa sebesar $22,30 \%$ dari seluruh kematian bayi di Indonesia disebabkan oleh pneumonia. Angka ini tidak jauh berbeda dari data yang didapatkan oleh survei mortalitas risketnas pada tahun 2007. Diketahui bahwa 23,80\% kematian bayi dan 15,50\% kematian balita disebabkan oleh pneumonia. ${ }^{1}$

Berdasarkan data dari Kemenkes 2011 tentang pola 10 penyakit terbanyak di rumah sakit di Indonesia, diketahui bahwa infeksi saluran pernapasan atas akut pun merupakan penyebab terbanyak kasus pada pasien rawat jalan, yaitu sebesar 291.356 kasus. Pada pasien rawat inap, pneumonia merupakan penyebab mortalitas terbanyak, yaitu sebesar $7,60 \%{ }^{1}$

Pneumonia dapat menyebabkan kematian bila tidak segera diobati. Pengobatan pneumonia terdiri atas antibiotika dan pengobatan suportif. Pemberian antibiotika sebaiknya berdasarkan pada mikroorganisme penyebab dan hasil uji kepekaannya. Terapi empiris perlu segera diberikan sementara menunggu hasil pemeriksaan dari laboratorium mikrobiologi, selanjutnya barulah dilakukan penyesuaian pemberian antibiotika untuk mendapatkan hasil yang maksimal. ${ }^{3}$

Pola kepekaan kuman terhadap antibiotika cenderung berubah selaras dengan pemakaian antibiotika itu sendiri. Salah satu hal yang mengkhawatirkan akhir - akhir ini adalah peningkatan resistensi bakteri penyebab ISPA terhadap beberapa antibiotika. Banyak antibiotika yang tidak lagi efektif untuk pengobatan karena resistensi bakteri yang timbul akibat penggunaan antibiotika yang tidak benar dan tidak tepat. Direktorat Bina Farmasi Komunitas dan Klinik DEPKES RI menyatakan bahwa dalam sepuluh tahun belakangan ini telah ditemukan peningkatan resistensi pneumococcus terhadap antimikroba golongan Penicillin. Hal ini mungkin juga akan berdampak terhadap meningkatnya resistensi terhadap beberapa golongan antimikroba lain seperti Cefalosporin, Makrolide, Tetracycline, serta Cotrimoksazole. $^{4}$

Peningkatan resistensi bakteri penyebab pneumonia terhadap beberapa antibiotika yang lazim digunakan oleh klinisi dalam pemberian terapi empirik tentu akan menyebabkan berkurangnya keefektifan terhadap terapi pneumonia. Hal ini tentu akan menyebabkan semakin tingginya morbiditas dan mortalitas yang disebabkan oleh infeksi pneumonia. Hal ini merupakan masalah yang harus segera diatasi mengingat pasien pneumonia semakin bertambah dari hari ke hari. Kecenderungan perubahan resistensi, dampak klinis, dan perubahan spektrum etiologi merupakan alasan penting mengapa pola kepekaan kuman terhadap antibiotika perlu dimonitoring secara teratur. Upaya ini untuk mengarahkan klinisi dalam pemberian antibiotika sekaligus menentukan strategi dalam pengendalian resistensi kuman patogen terhadap antibiotika. 


\section{METODE}

Jenis penelitian yang digunakan adalah deskriptif retrospektif dengan analisa data catatan hasil pemeriksaan tes biakan dan tes sensitivitas pada pasien pneumonia yang diperiksa di Laboratotium Mikrobiologi RSUP Dr. M. Djamil Padang selama satu tahun mulai tanggal 1 Januari - 31 Desember 2011.

\section{HASIL}

Penelitian yang telah dilaksanakan di laboratorium mikrobiologi RSUP Dr. M. Djamil Padang dengan mengambil data hasil pemeriksaan biakan dan tes sensitivitas pasien yang didiagnosa pneumonia periode Januari 2011 - Desember 2011, didapatkan data pasien yang mempunyai hasil uji biakan berupa bakteri dan yang dilakukan tes kepekaan terhadap antibiotika adalah sebanyak 432 kasus. Hasil uji ini memberikan data tentang jenis bakteri penyebab dan antibiotika yang sensitif serta resisten.

Semua kasus yang diteliti mempunyai data hasil tes biakan dan tes sensitivitas yang lengkap, yaitu: 358 kasus dengan satu jenis bakteri penyebab dan 74 kasus dengan dua jenis bakteri penyebab. Mengenai hasil tes biakan pada pasien pneumonia periode 2011 didapatkan hasil dengan ditemukannya bakteri penyebab seperti dapat dilihat pada Tabel 1 .

Tabel 1. Distribusi bakteri penyebab pneumonia pada penderita pneumonia yang diperiksa di laboratorium Mikrobiologi RSUP. Dr. M. Djamil Padang Periode Januari - Desember 2011

\begin{tabular}{lcc}
\hline Hasil Tes Biakan & Jumlah & $\%$ \\
\hline Klebsiella sp & 181 & 41,90 \\
Streptococcus $\alpha$ hemolitycus & 118 & 27,31 \\
Klebsiella sp dan Streptococcus $\alpha$ & 44 & 10,19 \\
hemolitycus & 47 & 10,88 \\
Staphylococcus aureus & 21 & 4,86 \\
Pseudomonas aeruginosa & & \\
Klebsiella sp dan Staphylococcus & 7 & 1,62 \\
aureus & & \\
Streptococcus $\alpha$ hemoliticus dan & 4 & 0,93 \\
Pseudomonas aeruginosa & 4 & 0,93 \\
Proteus sp & & \\
Proteus sp dan Pseudomonas & 1 & 0,23 \\
aeruginosa & 3 & 0,69 \\
Basillus & 1 & 0,23 \\
Escherichia coli & 1 & 0,23 \\
Enterobacter & 432 & 100 \\
\hline Jumlah & &
\end{tabular}

Pada Tabel 1 dapat dilihat bahwa pada pasien pneumonia yang diperiksa sputumnya dapat ditemukan satu bakteri atau dua bakteri sekaligus pada hasil biakannya. Penemuan terhadap satu bakteri, Klebsiella sp adalah sebagai bakteri yang paling banyak ditemukan yaitu sebanyak 181 kasus (41,90\%). Klebsiella sp dan Streptococcus $a$ hemolitycus sebanyak 118 kasus (10,19\%) adalah yang terbanyak untuk penemuan terhadap dua bakteri sekaligus pada hasil tes biakan pada pasien pneumonia.

Tabel 2. Tingkat resistensi antibiotika yang diuji terhadap bakteri penyebab pneumonia yang diperiksa di laboratorium Mikrobiologi RSUP Dr. M. Djamil Padang periode Januari - Desember 2011

\begin{tabular}{lc}
\hline Antibiotika & Rerata \\
\hline Ampicillin & $76 \%$ \\
Ampicillin + Sulbactam & $36 \%$ \\
Amoxicillin & $0 \%$ \\
Amoxicillin + Clavulanic Acid & $47 \%$ \\
Nalidixic Acid & $0 \%$ \\
Tetracyclin & $61 \%$ \\
Choramphenicol & $61 \%$ \\
Erithromycin & $76 \%$ \\
Sulfamethroxazole + Trimethroprime & $66 \%$ \\
Nitrofurantoin & $0 \%$ \\
Cefotaxime & $4 \%$ \\
Gentamycin & $46 \%$ \\
Cifrofloxacin & $40 \%$ \\
Ceftriaxone & $44 \%$ \\
Ceftazidine & $30 \%$ \\
Cefixime & $65 \%$ \\
Netilmicin & $9 \%$ \\
Cefoperazone & $41 \%$ \\
Sulbactam + Cefoperazone & $20 \%$ \\
Meropenem & $22 \%$ \\
\hline
\end{tabular}

Berdasarkan Tabel 2 di atas dapat dilihat bahwa rata-rata terhadap bakteri penyebab pneumonia, didapatkan antibiotika yang tingkat resistensi yang tinggi berturut-turut: Erythromycin (76,33\%), Ampicillin (76,28\%), Sulfamethroxazole + Trimethroprime $(66,22 \%)$, Tetracyclin $(61,31 \%)$ dan Choramphenicol $(60,63 \%)$. 


\section{PEMBAHASAN}

Berdasarkan analisis data hasil penelitian didapatkan bakteri penyebab pneumonia di Laboratorium RSUP. Dr. M. Djamil Padang periode 2011 adalah : Klebsiella sp (47,54\%), Streptococcus $\alpha$ hemolitycus $(38,43 \%)$, Staphylococcus aureus (12,50\%), Pseudomonas aeruginosa (6,02\%), Proteus sp (1,16\%), Basillus (0,70\%), Enterobacter (0,23\%), dan Escherichia coli (0,23\%). Penyebab pneumonia menurut literatur adalah bakteri terbanyak dari golongan Streptococcus pneumoniae, Staphylococcus aureus, Staphylococcus piogenes, Klebsiella sp (Friedlander bacillus), Escherichia coli, dan Pseudomonas aeruginosa. ${ }^{5}$ Berdasarkan laporan lima tahun terakhir dari beberapa pusat paru di Indonesia (Medan, Jakarta, Surabaya, Malang, Makasar) diketahui bahwa penyebab pneumonia terdiri dari: Klebsiella sp (45,18\%), Streptococcus pneumoniae (14,04\%), Streptococcus viridans (9,21\%), Staphylococcus aureus (9\%), Pseudomonas aeruginosa (8,56\%), Streptococcus hemolitycus (7,89\%), Enterobacter (5,26\%), dan Pseudomonas sp $(0,9 \%)$. Jadi, untuk bakteri penyebab pneumonia terbanyak yaitu Klebsiella sp didapatkan data yang relevan antara data di atas dengan data yang didapatkan di laboratorium mikrobiologi RSUP. Dr. M. Djamil Padang periode 2011. Sedangkan untuk bakteri penyebab pneumonia lainnya terdapat sedikit perbedaan persentase dan komposisi. ${ }^{3}$

Netilmicin memiliki tingkat kepekaan paling tinggi terhadap lima besar bakteri penyebab pneumonia di laboratorium mikrobiologi RSUP. Dr. M. Djamil Padang periode 2011, yaitu sebanyak $84,29 \%$. Netilmicin merupakan antibiotika golongan aminoglikosida yang baru dipasarkan oleh karena itu pemakaian antibiotika ini belum terlalu sering. Paparan Netilmicin terhadap bakteri belum terlalu sering oleh karena itu tingkat kepekaan terhadap antibiotika ini masih tinggi. Tingkat kepekaan yang tinggi terhadap bakteri penyebab pneumonia tersebut juga didapatkan berturut - turut terhadap Meropenem dan Sulbactam + Cefoperazone. Meropenem merupakan antibiotika lini ketiga sedangkan Sulbactam + Cefoperazone merupakan antibiotika lini kedua. Paparan antibiotika ini terhadap bakteri belum terlalu sering, oleh karena itu tingkat kepekaan terhadap antibiotika ini masih tinggi. ${ }^{6,7}$
Erithromycin memiliki tingkat resistensi paling tinggi, yaitu sebanyak 76,33\%. Tingkat resistensi yang tinggi juga didapatkan berturut - turut terhadap ampicillin, sulfamethroxazole + trimethroprime, tetracyclin, dan choramphenicol. Resistensi terhadap antibiotika ini disebabkan karena antibiotika ini merupakan antibiotika lini pertama. Antibiotika lini pertama merupakan antibiotika yang pertama kali dipakai untuk mengobati suatu infeksi. Pemakaian antibiotika yang irasional juga menyebabkan tingginya tingkat resistensi terhadap antibiotika ini. ${ }^{8,9}$

Beberapa bakteri secara intrinsik resisten terhadap golongan antibiotika tertentu. Bakteri dikatakan resisten apabila pertumbuhannya tidak dapat dihambat oleh antibiotika pada kadar maksimum yang dapat ditolerir oleh pejamu. Namun demikian, spesies bakteri yang secara normal memberikan respon terhadap antibiotika tertentu mungkin menyebabkan berkembangnya strain yang resisten. Munculnya strain resisten tersebut disebabkan oleh penggunakan antibiotika yang tidak rasional dan tidak hati-hati pada keadaan yang mungkin pasien dapat sembuh tanpa pengobatan atau pada keadaan yang tidak membutuhkan antibiotika. Resistensi antibiotika mungkin terjadi karena beberapa mekanisme seperti perubahan pada tempat target kerja antibiotika pada sel bakteri, rendahnya penetrasi obat karena menurunnya permeabilitas dan meningkatnya produksi enzim yang menginaktifkan antibiotika tersebut. ${ }^{10}$

\section{KESIMPULAN}

Klebsiella $s p$ adalah bakteri yang paling sering ditemukan pada sputum pada penderita pneumonia yang diperiksa di laboratorium mikrobiologi RSUP Dr. M. Djamil Padang periode 2011

Resistensi tertinggi bakteri penyebab pneumonia terhadap antibiotika di laboratorium mikrobiologi RSUP Dr. M. Djamil Padang periode 2011 adalah erithromycin dan tingkat kepekaan tertinggi adalah netilmicin

\section{DAFTAR PUSTAKA}

1. Kementrian Kesehatan Republik Indonesia. Profil kesehatan Indonesia 2010. Jakarta. Kementrian Kesehatan Republik Indonesia; 2011. 
2. Djoko W. Penyakit infeksi emerging dan reemerging dan dampaknya terhadap masalah kesehatan di Indonesia. Majalah Kedokteran Indonesia. 2005;55(3):181-6.

3. Priyanti Z.S, Marase L, Ida B. Pneumonia komuniti, pedoman diagnosis dan penatalaksanaan di Indonesia. Jakarta: Perhimpunan Dokter Paru Indonesia; 2005.

4. Departemen Kesehatan Republik Indonesia. Pharmaceutical care untuk pasien infeksi saluran pernapasan. Jakarta: Departemen Kesehatan Republik Indonesia; 2005.

5. Price SA, Wilson LM. Penyakit pernapasan restriktif. Dalam: Buku Ajar Patofisiologi Jilid 2. Edisi ke-6. Jakarta: EGC; 2006. hlm. 700-15.

6. Refdanita. Pola kepekaan kuman terhadap antibiotika di ruang rawat intensif rumah sakit Fatmawati Jakarta tahun 2001-2002. Makara Kesehatan. 2004;8(2):41-8.
7. Mycek MJ, Harvey RA. Champe PC. Prinsip prinsip terapi antimikroba. Dalam: Buku Ajar Farmakologi. Edisi ke-2. Jakarta: Widya Medika; 2001.hlm. $283-92$.

8. Aru WS, Setiyohadi B, Alwi I. Pneumonia. Dalam: Buku Ajar IImu Penyakit Dalam. Jilid 2. Edisi ke-4. Jakarta: FKUI; 2006. hlm.801-18.

9. Haider BA, Lassi ZS, Bhutta ZA. Short-course versus long-course antibiotic therapy for non-severe community-acquired pneumonia in children aged 2 months to 59 months. Cochrane Database of Systematic Reviews. 2008 (diunduh 24 April 2012). Tersedia dari: URL: HYPERLINK http://www.ncbi.nlm.nih.gov/pubmed

10. AgusS, Ikaningsih, Sudiro TM. Profil etiologi bakteremi dan resistensinya terhadap antibiotika di rumah sakit Cipto Mangunkusumo, Jakarta tahun 1999 - 2002. Majalah Kedokteran Indonesia. 2004;54(7):260-5. 